\title{
有機溶媒中の芳香族化合物 の音速度
}

(昭和 42 年 9 月 8 日受理)

野 村 浩康・宮 原豊*1

$1 \mathrm{Mc}$ の超音波干涉計を用いて，トルェンおよびメチルェチルケトン中で種々の芳香族化合物の音速度を測定した。各浱度での

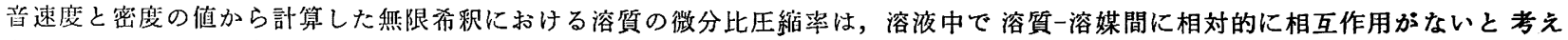
られるときには溶質自身の圧縮率を示した。溶質一溶媒間に相当作用があるときには，その強さに比例して微分比圧箱率の值は溶 質自身の圧縮率の值より小さくなった。安た，ての微分比圧縮率の值は分子内の官能基について加成性が成立した。同時に和田の 分子圧縮に基づく能本の式から得られる仮想的な溶質液体の圧縮率は，溶媒によらずほとんど一致した。

\section{1 緒 言}

液体あるいは溶液の圧縮率は系の状態に密接に関係した一つの 巨視的な量である。しかし現段階においては，液体あるいは溶液 の圧縮率に関して, 統計力学に基うく微視的な議論は二三の簡単 な液体りや正則溶液りの場合をのぞいてまだ十分発達していない。 しかしながら，電解質水溶液や糖類の水溶液などの溶液中で溶質 に溶媒和があるような場合には，適当な模型から出発して溶液の 玨縮率の值から水和量を求めることができる344。

非電解質水溶液の音速度については, 宮原 5 多有機酸について, また宮原，和佐田6) はアルコール類，アミノ酸について，その微 分此圧縮の值が，溶質分子の各官能基について加成性がなり立つ ことを報告している。また Rothhardt? ${ }^{2}$ はベンゼンーメタノール 系の王縮率の测定から，溶質-溶媒間の $\pi$ 電子-OH 基間の相互 作用定論じている。

著者らは種々の芳香族化合物のトルエンおよびメチルエチルケ トン溶液の音速度を測定し, 各物質と両溶媒との相互作用, 微分 比圧縮率の官能基についてこの加成性を調べた。

\section{2 定義}

無限希釈における溶質の微分比圧縮率を次式で定義する。

$$
\bar{\kappa}_{20}=-\frac{1}{\bar{v}_{20}}\left(\frac{\partial \bar{v}_{2}}{\partial P}\right)_{0, s}
$$

ここで， $\bar{v}_{2}$ は溶質の微分比容，添字 0 は無限希釈を表わす。こ の $\bar{\kappa}_{20}$ は実験的には次式から求める ${ }^{8)}$ 。

$$
K_{x}=\left(\frac{D-x}{D_{1}}-\frac{\kappa}{\kappa_{1}}\right) \frac{1}{x}, \bar{\kappa}_{20}=-\frac{\kappa_{1}}{\bar{v}_{20}} \lim _{x \rightarrow 0} K_{x}
$$

*1 Hiroyasu Nomura, Yutaka Mryahara 名古屋大学工 学部化学工学教室, 名古屋市千種区不老町

1) S. A. Rice, P. Gray, "The Statistical Mechanics of Simple Liquid ", John Wiley \& Son.(1965)Chapter 2.

2) J. G. Kirkwood, E. P. Buff, J. Chem. Phys., 19, 774 (1951).

3) B. Lunden, Z. Phys. Chem., 192, 345(1943); A. Passynsky, Acta. Physicochimica URSS, 22, 137(1947); B. B. Owen, P. L. Kronick, J. Phys. Chem., 65, 84(1964).

4) 宮原 豊, 椎尾一, 日化, 72, 876(1951).

5) Y. Miyahara, Bull. Chem. Soc. Japan, 25, 326(1952).

6) 宮原 豊, 和佐田宣英, 化学の領域, 12, 515(1958).

7) L. Rothhardt, Z. Physik. Chem., 204, 215(1955); 205, 2206(1956).

8) H. Nomura, Y. Miyahara, J. Applied Polymer Sci., 8, 1643(1964).
ここで， $D ， \kappa$ はそれぞれ溶液の密度および圧維率を， $x$ は $\mathrm{g} / \mathrm{cc}$ (溶液)であらわした濃度である。添字 1 は純溶媒での值を示す。 また溶液中で溶質に溶媒和がある場合には，簡単な模型を仮定 すると，微分比圧縮率はつぎのように書ける8)。

$$
\bar{\kappa}_{20}=\kappa_{2}+\frac{\omega}{\bar{v}_{2.0}}\left(\kappa_{1}-\kappa_{s}\right)
$$

ここで， $\kappa_{1}, \kappa_{2}, \kappa_{s}$ はそれぞれ溶媒, 溶質, 溶媒和領域での溶媒 の圧縮率, $\omega$ は溶媒和量 $(\mathrm{cc} / \mathrm{g})$ を示す。

\section{3 実験}

溶液中の音速度および密度の測定は既報9と同じであり，溶液 中の音速度の測定には $1 \mathrm{Mc}$ の超音波千涉計を用いた。測定温度 はすべて $34.00 \pm 0.02^{\circ} \mathrm{Gであった。}$

試料は, いずれも東京化成株式会社製, 試薬特級のものをその まま用いた。溶媒トルエンおよびメチルエチルケトンは市販特級 品を常法で脱水, 再蒸留して用いた。

\section{4 結果とその考察}

実験結果の一例として, メチルエチルケトン中のカテコールの 各濃度に対する $\left(D-x / D_{1}\right)$ と， $\pi / \kappa_{1}$ の関係を図 1 に示す。図 1 か

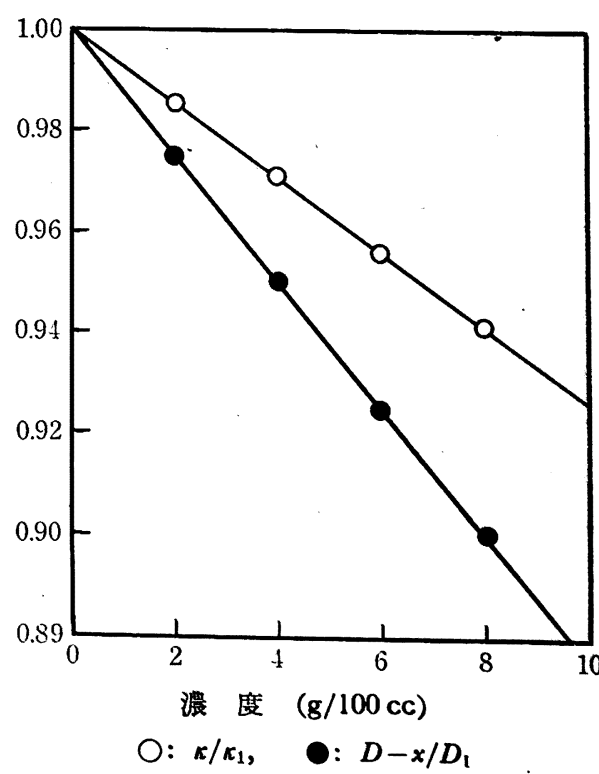

$\kappa ， D$ はそれぞれ溶液の圧㢈事と密度, 添字 1 は純溶媒を示す。

因 
表 1 トルェンおよびメチルェチルケトン中の微分比圧縮率

\begin{tabular}{|c|c|c|c|c|c|c|}
\hline & \multirow{2}{*}{ 分子量 } & \multirow{2}{*}{$\kappa_{2}\left(\times 10^{12}\right)$} & \multicolumn{2}{|c|}{ メチルェチルケトン } & \multicolumn{2}{|c|}{ トルエン } \\
\hline & & & $\bar{\kappa}_{20} \times 10^{12}$ & $\bar{v}_{20}$ & $\bar{\kappa}_{20} \times\left(10^{12}\right)$ & $\bar{v}_{20}$ \\
\hline ペン ゼ ン & 78 & 69.6 & 65.2 & 1.156 & 70.4 & 1.162 \\
\hline$フ \pm ノ-ル$ & 94 & - & -13.2 & 0.892 & 21.3 & 0.948 \\
\hline カテコール & 110 & - & -64.7 & 0.742 & -58.1 & 0.845 \\
\hline 安 息 香 酸 & 122 & - & -33.7 & 0.809 & 24.1 & 0.868 \\
\hline フ マ ル 酸 & 164 & - & -107.2 & 0.638 & - & - \\
\hline サリチル酸 & 138 & - & -25.3 & 0.743 & - & - \\
\hline シクロヘキサン & 84 & 100.6 & 104.0 & 1.353 & 91.0 & 1.330 \\
\hline シクロへキサノール & 100 & 51.6 & -1.8 & 1.071 & 39.2 & 1.105 \\
\hline ヘキサヒドロ安息香酸 & 128 & 52.2 & 1.0 & 0.940 & 40.2 & 0.971 \\
\hline ナフタリン & 130 & - & -4.4 & 0.957 & 30.5 & 0.984 \\
\hline フントラセン & 178 & - & -35.4 & 0.864 & -15.7 & 0.908 \\
\hline ス チ レ ン & 104 & 60.0 & 44.3 & 1.101 & 59.0 & 1.120 \\
\hline ジフェニルメタン & 168 & 44.9 & 13.1 & 0.970 & 33.0 & 0.982 \\
\hline ペンゾフェノン & 182 & - & 40.0 & 0.900 & 8.9 & 0.896 \\
\hline ジフェニルェーテル & 170 & 44.3 & -4.8 & 0.850 & 28.9 & 0.936 \\
\hline ビフェ = ル & 154 & -- & - & 一 & 23.4 & 0.973 \\
\hline$p$-テルフェニル & 231 & - & - & - & -63.5 & 0.921 \\
\hline
\end{tabular}

ら明らかなように $\left(D-x / D_{1}\right)$ と $\kappa / \kappa_{1}$ は，いずれも濃度に対して 直線関係にある。このような関係は両溶媒中で，いずれの試料に ついても得られた。

両溶媒中の各試料についての実験結果を表 1 に示す。表中 $\kappa_{2}$ は溶質試料が測定温度で液体であるものについて実測した圧縮率 の值である。

式 (3)から明らかなように，溶液中で 溶質-溶媒間に相互作用 が相対的にないとき $(\omega=0), \bar{\kappa}_{20}=\kappa_{2}$ となる。このことは各種有 機溶媒中の酢酸ビニルモノマーについては宮原, 増田10》よって 確かめられているが，本実験でも表 1 からわかるように，トルエ ンおよびメチルエチルケトン中のベンゼン, シクロヘキサンなど については $\bar{\kappa}_{20}$ の値は溶質液体自身の圧縮率を示している。

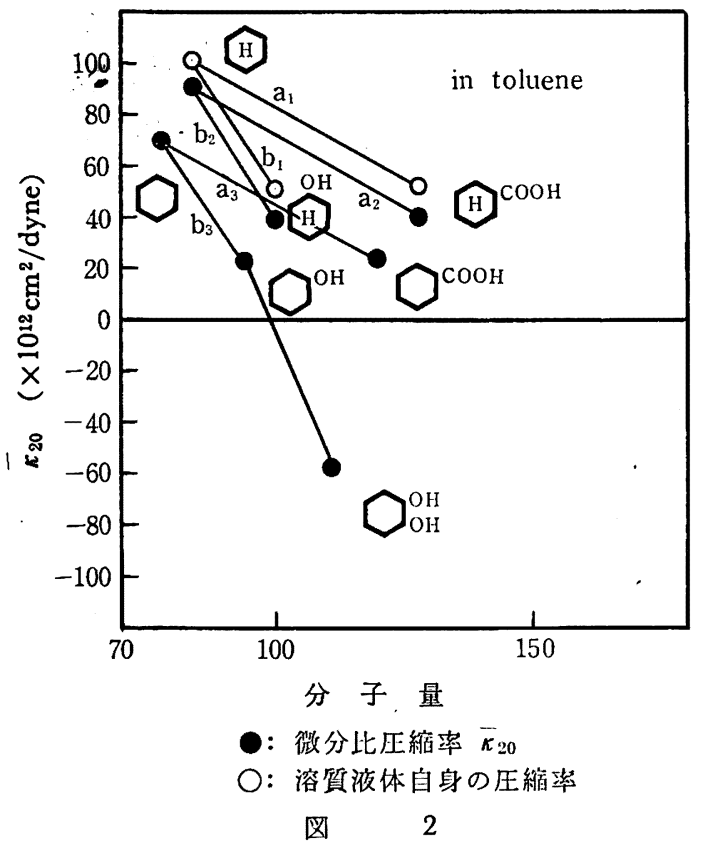

9）宮原 豊，增田勇三，日化，81，692(1960).

10）宮原 豊，增田勇三，科学，30，588(1960).

\section{1 両溶媒中のフェノール類および芳香族カルボン酸}

表 1 中のフェノール類および芳香族カルボン酸についての $\bar{\kappa}_{20}$ の值を分子量に対してプロットした図を，トルエン中の場合を困 2 に,メチルエチルケトン中の場合を図 3 K示す。眓中には同時 に溶質自身の圧縮率が○印でプロットしてある。

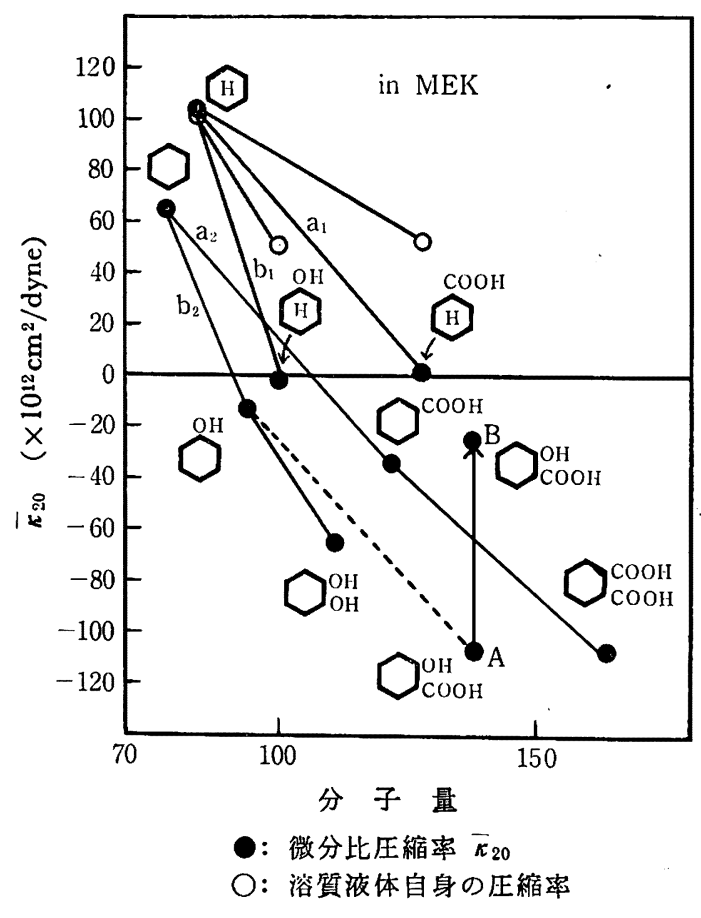

図 3

図 2 から明らかなように，トルエン中のシクロヘキサンーヘキ サヒドロ安息香酸の微分比圧縮率 $\overline{\boldsymbol{\kappa}}_{20}$ 開の関係と，ベンゼン，安 息香酸の微分比圧縮率 $\kappa_{2}$ 間の関係はまったく同一である。すな わち, 四 2 で $\mathrm{a}_{2}, \mathrm{a}_{3}$ の直線はまったく平行になり, 溶質液体シ クロヘキサン，ヘキサヒドロ安息香酸自身の压繀涾 $\kappa_{2}$ 問の関係 もこれに一致する。いいかえれば，図 2 で直線 $a_{1}, a_{2}, a_{3}$ はた がいに平行になる。このことからカルボキシル基について -49 
$\times 10^{-12} \mathrm{~cm}^{2} /$ dyne という值を制りつけることができる。また同椂 に，溶質液体シクロヘキサン，シクロヘキサノール自身の圧縮黍 $\kappa_{2}$ 間の関係亡, トルエン中のシクロヘキサン, シクロヘキサ, ールの微分比压縮率 $\bar{\kappa}_{20}$ 間の関係，またベンゼン，フェノール の $\bar{\kappa}_{20}$ 間の関係はたがいにまったく同じになる(図 2 で $\mathrm{b}_{1}, \mathrm{~b}_{2}$, $\mathrm{b}_{3}$ はたがいに平行になる)。このことから水酸基について， -50 $\times 10^{-12} \mathrm{~cm}^{2} /$ dyne という值を制りつけることができる。一方, トルエン中のベンゼンの $\bar{\kappa}_{20}$ の値は，ベンゼン自身の圧縮率 $\kappa_{2}$ とまったく同一になるが，シクロヘキサン，シクロヘキサノー ル，ヘキサヒドロ安息香酸の $\bar{\kappa}_{20}$ の值は，各溶質液体自身の灰 縮率より約 10 小さくなっている。乙の差は，溶媒ベンゼンと溶 質のシクロヘキサン核との相互作用によるものと考えられる。

また図 3 から明らかなように，微分比圧縮率 $\bar{\kappa}_{20}$ はメチルエチ ルケトン中でも, トルエン中と同様, 水酸基, カルボキシル基, フェニル基，シクロヘキシル基についての加成性がだいたいなり 立っている。 $\bar{\kappa}_{20}$ がメチルエチルケトン中で，これらの基につい て加成性がなり立っているとすると，サリチル酸の $\bar{\kappa}_{20}$ の值は図 3 中，点Aのところにこなくてはならないが，これより大きくは ずれて点 $\mathrm{B}$ のころにくる。これはよく知られているように，サ リチル酸が分子内で分子内キレート[1]をつくっているためと考 えられる。<smiles>Oc1ccccc1O</smiles>

[1]

4.2 両溶媒中のナフタリン, アントラセン, およびビフェニル, $\boldsymbol{p}$-テルフェニル

トルエン中のこれらの化合物の $\bar{\kappa}_{20}-M$ 図を図 4 に, メチルエ チルケトン中の $\bar{\kappa}_{20}-M$ 図を図 5 に示す。図 4 および図 5 から明 らかなように，両溶媒中でともに縮合環の個数について，またフ ェニル基の数についてかなりの加成性が $\bar{\kappa}_{20}$ にあると考えられ る。

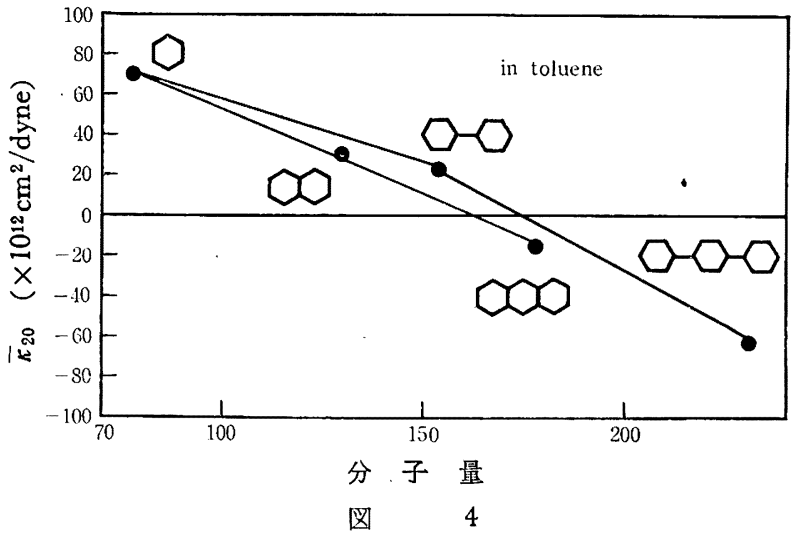

\section{3 両溶媒中のその他の化合物}

トルエンおよびメチルエチルケトン中のスチレン，ジフェニル メタン，ベンゾフェノン， ジフニルエーテルについての $\bar{\kappa}_{20}$ $M$ 図を図 6,7 に示与。図中には，溶質液体自身の正䋱素も○印 で同㭙にプロットしてある。図から明らかなように $\bar{\kappa}_{20}-M, \bar{\kappa}_{2-}$ $M$ の関係はほぼ固線闒係になっている。またいずれの物質につ いても， $\bar{\kappa}_{20}<\kappa_{2}$ で好る。式(3)多らも明らふな上うに，溶液中

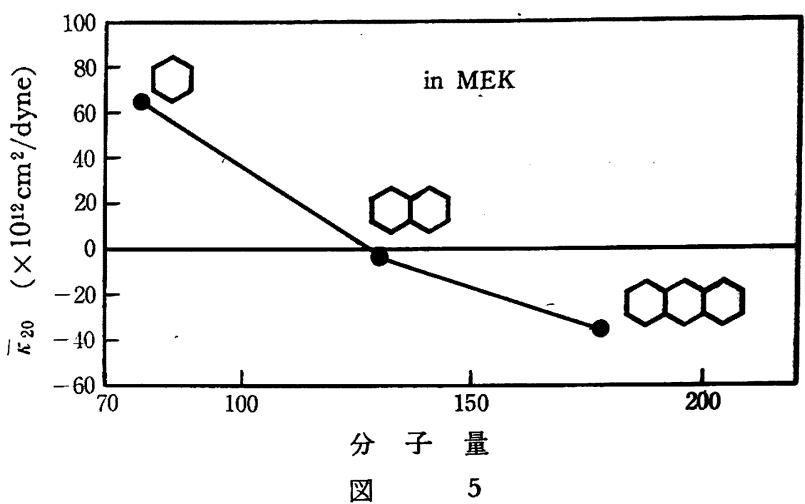

で溶質一溶媒間に相互作用が相対的にないとすると, $\overline{\boldsymbol{\kappa}}_{20}=\boldsymbol{\kappa}_{2}$ とな るはずであるから， $\kappa_{2}$ と $\bar{\kappa}_{20}$ との差は溶質-溶媒間の相互作用 を表わすものと考えることができる。

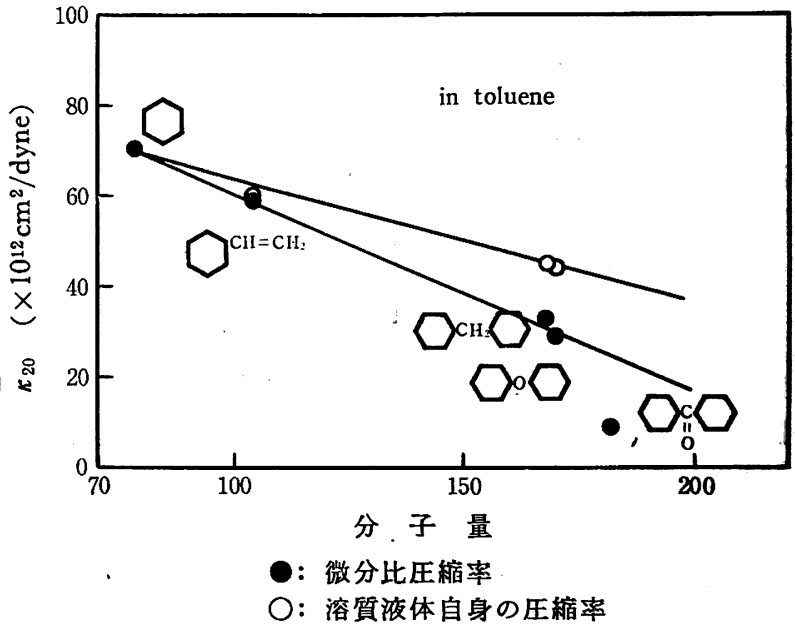

図 6

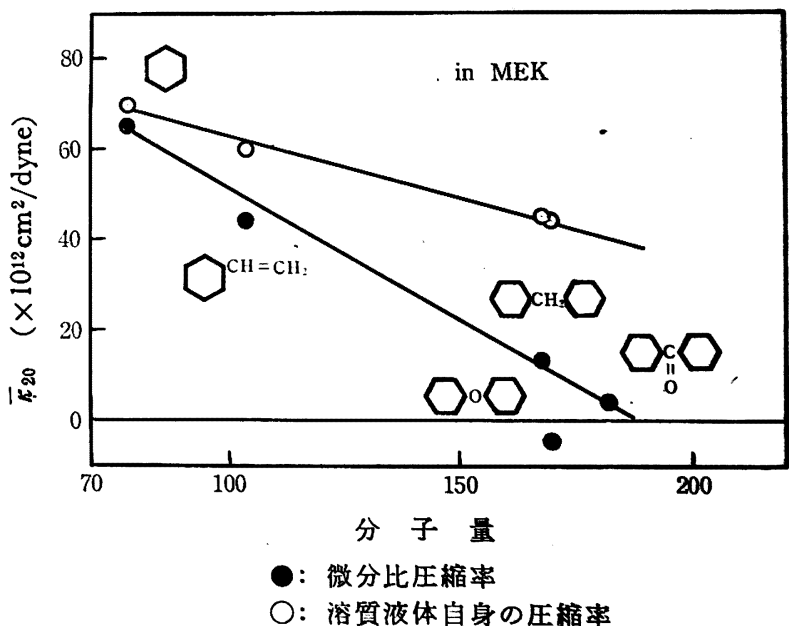

图 7

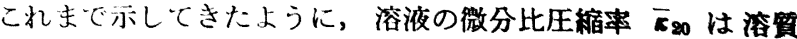
分子を惯成している各守能些について加成性がなり立っていると 考えることができる。このような加成性は，アミノ酸の水溶渡の 場合には比容について成立するい。また，液体自身の物理量がそ

11) C. Edsall, "Proteins Aminoacids and Peptides", Reinhold(1943) Chapter 16. 
の構成官能基について加成性を示すような例は分子屈折，パラコ 一ルなどがあり，また Rao の分子音速度 ${ }^{12)}$, 和由の分子圧縮率13) についても同様の加成性が成立することが報告されている。これ らの加成性について，分子諭的説明はいまのところできないが， 本実験の微分比圧縮率の加成性については溶液中の溶質-溶媒間 の van der Waals 力に加成性があるため， $\bar{\kappa}_{20}$ に加成性がある と推論でき, 同時に $\bar{\kappa}_{20}$ の值は溶質一溶媒間の相対的な相互作朋 の尺度となっている。

\section{4 和田-能本の式にしたがう仮想的液体の圧縮率}

能本によれば14)，多くの二成分混合液体について和田15)の分子 圧縮率と呼ばれる量 $W$ が，モル分率の一次式であらわされる。

$$
W=W_{1}\left(1-x_{2}\right)+W_{2} x_{2}
$$

ここで $W, W_{1}, W_{2}$ は溶液および 各成分の和田の分子圧縮努， $x_{2}$ 注成分 2 のモル分率である。ここで和田の分子正縮率 $W$ は次 式で定義される。

$$
W=\frac{M}{\rho \kappa^{1 / 7}}
$$

ここで，M分子量， $\rho$ は密度， $\kappa$ は断熱正縮率である。( 4$)$, (5)式を用いて 無限希釈における微分比圧縮率 $\bar{\kappa}_{20}$ を計算する と次式が得られる10)。

$$
\left.\begin{array}{l}
\bar{\kappa}_{20}=7 \kappa_{1}\left\{\frac{8}{7}-\frac{1}{\delta}\left(\frac{\kappa_{1}}{\kappa_{2}^{W}}\right)^{1 / 7}\right\} \\
\delta=\frac{\bar{v}_{20}}{v_{2}}
\end{array}\right\}
$$

表 1 の $\kappa_{1} ， \bar{\kappa}_{20}$ の実験值から，（5)式を用いて計算した $\kappa_{2}^{W}$ の值を表 2 に示す。表から明らかなように，溶媒の種類が異なっ てもまた各溶液中の $\bar{\kappa}_{20}$ の值がいちじるしく翼なっても $\kappa_{2}^{W}$ の

12) M. Rama, M. R. Rao, J. Chem. Phys., 9, 682(1941).

13) F. Danusso, Ric. Sci., 20, 1481(1950).

14) O. Nomoto, J. Phys. Soc. Japan, 8, 553(1953); 13, 1524(1958); J. Chem. Phys., 21, 950(1953).

15) H. Wada, J. Phys. Soc. Japan, 4, 280(1949).
值はほぼ同じになり，これは溶質液体自身の正縮率にほぼ等しく なっている。このことは種々の溶媒中の酢酸ビニルモノマー, ポ リ酢酸ビニルについての宮原，増田の結果 ${ }^{10)}$ と同様である。すな わち $\kappa_{2}^{W}$ は溶質が溶液中で示与仮想的な液体とれ自身の压縮染を

\begin{tabular}{|c|c|c|c|}
\hline & $2\left(\times 10^{12}\right)$ & $\begin{array}{c}\text { メチルエチルケト } \\
\text { ン } \kappa_{2}^{W}\left(\times 10^{12}\right)\end{array}$ & 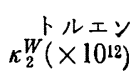 \\
\hline ベンゼン & 69.0 & 70.1 & 70.4 \\
\hline$>x,-ル$ & - & 31.8 & 36.9 \\
\hline カテコール & - & 19.9 & 19.0 \\
\hline 安息 香 酸 & - & 27.2 & 38.2 \\
\hline ᄀ $、$ 酸 & - & 14.5 & - \\
\hline サリチル酸 & - & 29.0 & - \\
\hline シクロへキサン & 100.6 & 94.7 & 94.2 \\
\hline シクローキサノール & 51.6 & 36.5 & 46.4 \\
\hline へキサヒドロ安息香酸 & 52.2 & 37.3 & 46.8 \\
\hline ナフタリン & - & 35.5 & 41.4 \\
\hline アントラセン & - & 27.7 & 23.5 \\
\hline$\pi \neq \nu \vee$ & 60.0 & 56.5 & 60.4 \\
\hline ジフェニメタン & 44.9 & 41.8 & 42.8 \\
\hline ベンゾフェノン & - & 38.4 & 31.6 \\
\hline ジフェニルエーテル & 44.3 & 39.4 & 40.6 \\
\hline$ヒ ゙ フ ェ=ル$ & - & - & 37.9 \\
\hline$p$-テルフェニル & - & - & 13.7 \\
\hline
\end{tabular}
示すものと考えられる。

表 2 和田・能本の式による仮想液体の圧縮泘

電解質水溶液や糖類の水溶液の場合, $\bar{\kappa}_{20}$ の值は負となり，(3) 式を用いて溶質の水和量を求めることができる。本実験の場合も メチルエチルケトン中のフェノール, 安息香酸などでは $\bar{\kappa}_{20}$ の值 は負となった。この原因が 溶質分子の溶媒和によるものであれ ば，(3)式と表 2 の $\kappa_{2}^{W}$ とから溶媒和量を求めることができる。 しかし，これには溶液の比熱とか, 活動度とかの測定で, いまの 溶液系について溶媒和の存在を確かめなければならない。 